Analisis Faktor Penyebab...(Nadianah Zavera, Heni Pujiastuti)

\title{
EFEKTIVITAS PEMBELAJARAN KECEPATAN TERHADAP KAPABILITAS KONEKSI MATEMATIS SISWA
}

\author{
Oleh: Nuriana R. Dewi, Mulyono, Miftah Fathur Rahmi P. \\ (Universitas Negeri Semarang) \\ Email nurianaramadan@mail.unnes.ac.id,mulyono.mat@mail.unnes.ac.id \\ miftahfathurrahmi@gmail.com
}

\begin{abstract}
Abstrak
Tujuan penelitian ini adalah untuk menganalisis keefektifan pembelajaran PACE terhadap kemampuan koneksi matematis siswa kelas X. Metode dalam penelitian ini adalah kuantitatif dengan desain penelitian true experimental design. Populasi dalam penelitian ini adalah seluruh siswa kelas X di salah satu Sekolah Menengah Atas di Banyumas tahun pelajaran 2018/2019. Kelas X MIPA 1 sebagai kelas eksperimen dan kelas X MIPA 8 sebagai kelas kontrol dipilih secara acak kelas. Metode pengumpulan data yang digunakan adalah tes. Analisis tes kemampuan koneksi matematis menggunakan uji homogenitas, uji normalitas, uji $t$, uji proporsi, uji kesamaan dua rata-rata, dan uji kesamaan dua proporsi. Hasil dari dari penelitian ini adalah pembelajaran PACE efektif terhadap kemampuan koneksi matematis siswa kelas X.
\end{abstract}

Kata Kunci : Kemampuan Koneksi Matematis, PACE

\section{THE EFFECTIVENESS OF PACE LEARNING ON STUDENT'S MATHEMATICAL CONNECTION CAPABILITIES}

\begin{abstract}
The purpose of this study was to analyze the effectiveness of PACE learning towards the mathematical connection ability of class $X$ students. The method in this study was quantitative with a true experimental design research design. The population in this study were all students of class $X$ in one of the High Schools in Banyumas in the academic year 2018/2019. Class X Mathematics and Natural Sciences 1 as an experimental class and Class $X$ Mathematics and Natural Sciences 8 as a control class were randomly selected classes. The data collection method used is a test. The analysis of mathematical connection ability tests uses homogeneity test, normality test, $t$ test, proportion test, two average similarity test, and two proportion similarity test. The results of this study are effective PACE learning on the mathematical connection ability of class $X$ students.
\end{abstract}

Keywords: Mathematical Connection Ability, PACE

\section{A. PENDAHULUAN}

Undang-Undang Republik Indonesia Nomor 20 Tahun 2003 Bab X Pasal 37 menyatakan bahwa matematika adalah mata pelajaran yang harus diberikan di 
sekolah dasar dan menengah. Jadi siswa belajar matematika mulai dari Sekolah Dasar, Sekolah Menengah, Sekolah Menengah dan Perguruan Tinggi. Konsep dan prosedur dalam matematika dapat digunakan dalam matematika dan bidang lainnya (Prasetyo et al., 2017). Bidang lain seperti fisika, kimia, biologi dan lainnya.

Berdasarkan Dewan Nasional Matematika Guru (NCTM) (2000), ada 5 standar kemampuan matematika siswa dalam pembelajaran, standar kemampuan ini adalah pemecahan masalah, penalaran dan bukti, komunikasi, koneksi, dan representasi. Kemampuan koneksi matematika adalah kemampuan siswa untuk mengenali representasi dari topik yang sama, menghubungkan langkah-langkah dalam representasi yang sama; dan menggunakan matematika dengan disiplin ilmu lain (Karnasih \& Sinaga, 2017).

Keterkaitan ini tidak hanya berlaku untuk topik-topik dalam matematika, tetapi juga berhubungan dengan disiplin ilmu lain dan berhubungan dengan kehidupan sehari-hari. Koneksi ini disebut koneksi matematis. Dewi \& Kusumah (2014) menyatakan bahwa keterampilan koneksi matematika diperlukan karena matematika adalah unit, konsep yang saling terkait. Dewan Nasional Matematika Guru (NCTM) (2000), menyatakan bahwa tanpa koneksi matematika siswa menjadi terlalu banyak belajar dan mengingat banyak konsep dan prosedur matematika yang terpisah.

Kemampuan untuk menghubungkan matematika menjadi ukuran penting keberhasilan dalam belajar matematika (Saminanto \& Kartono, 2015). Koneksi matematika sangat penting karena dengan kemampuan koneksi matematika siswa dapat memahami dan menghubungkan ide-ide mereka, membuatnya mudah untuk menghubungkan matematika antara topik dan dengan materi lain atau dengan kehidupan sehari-hari. Sejalan dengan Noto et all (2016) ini menyatakan bahwa siswa yang memiliki keterampilan koneksi yang baik akan merasa lebih mudah untuk belajar banyak materi dengan menghubungkan materi satu sama lain.

Namun, pentingnya kemampuan koneksi matematika di Indonesia belum tepat. Keterampilan koneksi matematika adalah kemampuan yang mencakup 
koneksi antara topik matematika, koneksi dengan disiplin ilmu lain, dan koneksi dengan kehidupan sehari-hari (Dewi \& Masrukan, 2018).

Hasil penelitian pendahuluan yang dilakukan oleh peneliti pada 68 siswa di sekolah penelitian pada Teori Material Teorema Pythagoras menunjukkan bahwa skor rata-rata untuk semua koneksi matematika adalah 14,2 dengan standar deviasi 5,8 dari skor ideal 40. Itu menunjukkan bahwa koneksi matematika di sekolah penelitian masih rendah.

Berikut ini adalah hasil dari karya siswa yang menunjukkan bahwa koneksi antara topik dalam matematika siswa masih rendah.

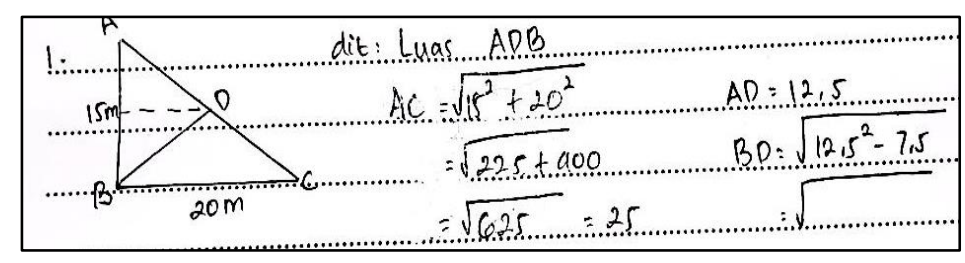

Berikut ini adalah salah satu hasil karya siswa yang menunjukkan bahwa koneksi dengan bidang lain masih rendah.

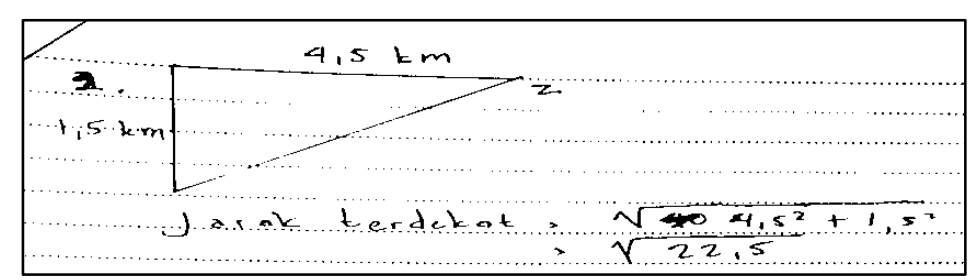

Berikut ini adalah salah satu hasil karya siswa yang menunjukkan bahwa koneksi dengan kehidupan sehari-hari masih rendah.

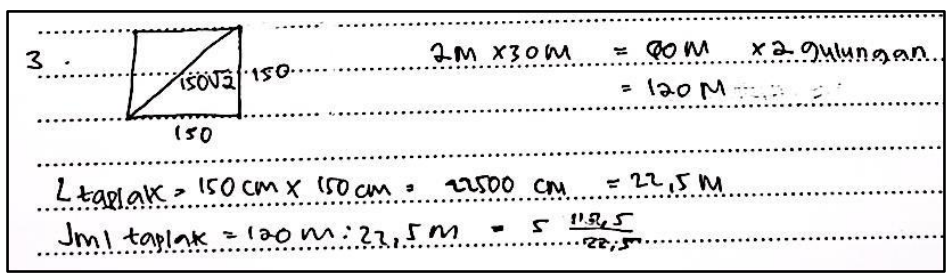

Berbagai model pembelajaran yang ada menunjukkan bahwa tidak ada satu cara terbaik untuk mengajar. Salah satu model pembelajaran yang dianggap merangsang realisasi kemampuan koneksi matematika adalah model pembelajaran PACE.

Pada tahun 1998, model pembelajaran PACE dikembangkan oleh Lee Carl. Lee (1998), PACE adalah model pembelajaran yang merupakan singkatan dari 
Project, Activity, Cooperative Learning, dan Exercise. PACE adalah model pembelajaran yang terdiri dari tahapan Kegiatan, pembelajaran Kooperatif, Latihan dan Proyek. Pembelajaran PACE adalah salah satu model pembelajaran yang menganut teori konstruktivisme (Suryana, 2015).

Pada tahap kegiatan siswa bekerja pada lembar tugas, lembar tugas digunakan untuk menemukan konsep yang sedang dipelajari dan untuk meninjau konsep yang telah dipelajari sebelumnya. Pada tahap pembelajaran kooperatif, siswa berkumpul dalam kelompok dan mendiskusikan masalah yang berkaitan dengan materi yang dipelajari siswa.

Tahap selanjutnya adalah latihan, pada tahap ini siswa diberikan lembar latihan, berguna agar siswa dapat lebih memahami materi yang telah dipelajari. Tahap terakhir adalah proyek, pada tahap proyek siswa diberikan tugas proyek yang diselesaikan dalam kelompok. Siswa memilih masalah mereka sendiri yaitu tentang kehidupan sehari-hari dan menyelesaikannya dalam bentuk laporan yang diikuti oleh presentasi.

Di sekolah penelitian menggunakan kurikulum 2013 dengan model pembelajaran Problem Based Learning (PBL). Menurut Padmavathy \& Mareesh (2013), Problem-Based Learning (PBL) menggambarkan lingkungan belajar di mana masalah mendorong pembelajaran.

Dengan melihat latar belakang ini tujuan dari penelitian ini adalah untuk menganalisis efektivitas pembelajaran PACE terhadap kemampuan koneksi matematika siswa kelas $\mathrm{X}$.

\section{B. METODOLOGI PENELITIAN}

Metode yang digunakan dalam penelitian ini adalah kuantitatif. Desain penelitian kuantitatif yang digunakan adalah desain eksperimen sejati yang merupakan bentuk desain kontrol hanya posttest.

Table 1. Posttest-Only Control Design Research Design

\begin{tabular}{ccc}
\hline Class Group & Treatment & Posttest \\
\hline Experimental (R) & $\mathrm{X}$ & $\mathrm{O}_{1}$ \\
Control (R) & & $\mathrm{O}_{2}$ \\
\hline
\end{tabular}


Analisis Faktor Penyebab...(Nadianah Zavera, Heni Pujiastuti)

Ket:

R: Koleksi acak

$\mathrm{X}$ : Belajar dengan model PACE

O_1: Posttest untuk kelas eksperimen

O_2: Posttest untuk kelas kontrol

Creswell (2015), populasi adalah sekelompok individu yang memiliki karakteristik khusus yang sama. Populasi dalam penelitian ini adalah semua siswa kelas X di salah satu SMA di Banyumas pada tahun akademik 2018/2019. Creswell (2015), sampel adalah subkelompok dari populasi target yang direncanakan untuk diselidiki oleh peneliti untuk menggeneralisasi tentang populasi target. Dalam penelitian ini sampel acak kelas diperoleh X Matematika dan Ilmu Pengetahuan Alam 1 sebagai kelas eksperimen diperlakukan dengan model pembelajaran PACE dan X Matematika dan Ilmu Pengetahuan Alam 8 sebagai kelas kontrol diperlakukan dengan model pembelajaran Problem Based Learning. Selain itu, peneliti juga memilih satu kelas untuk kelas tes, yaitu Kelas X Matematika dan Ilmu Pengetahuan Alam 5.

Prosedur penelitian dalam penelitian ini adalah sebagai berikut: (1) melakukan pengamatan di sekolah; (2) menentukan populasi penelitian yaitu semua siswa kelas $\mathrm{X}$; (3) mengambil penilaian semester akhir kelas $\mathrm{X}$ dalam Matematika dan Ilmu Pengetahuan Alam di semester ganjil tahun 2018/1019 tahun sekolah sebagai data awal; (4) data awal tentang nilai Penilaian Semester Akhir yang digunakan peneliti untuk menentukan normalitas, homogenitas, dan kesamaan dari dua rata-rata; (5) merancang kelompok kelas eksperimen, kontrol dan percobaan dengan teknik kelas acak; (6) menyusun instrumen penelitian (pertanyaan tes tentang kemampuan koneksi matematika dan perangkat pembelajaran); (7) belajar matematika; (8) melakukan uji coba kelas yang tidak digunakan sebagai kelas eksperimen dan kelas kontrol; (9) menganalisis uji coba untuk menentukan validitas, reliabilitas, tingkat kesulitan dan fitur yang membedakan; (10) menentukan item yang digunakan dalam tes berdasarkan data uji coba instrumen; (11) melakukan tes kemampuan koneksi matematika pada sampel penelitian (kelompok kelas eksperimen dan kontrol); (12) melakukan 
wawancara dengan subyek penelitian; (13) menganalisis dan memproses hasil tes untuk menguji hipotesis; (13) menyusun hasil penelitian; dan (14) menarik kesimpulan berdasarkan hasil penelitian yang diperoleh untuk menjawab rumusan masalah.

Sebelum menguji hipotesis data, hasil tes kemampuan koneksi matematis diuji normalitas, dengan uji homogenitas. Tes yang digunakan dalam penelitian ini adalah uji proporsi, uji kesamaan dua rata-rata dan uji kesamaan dua proporsi.

\section{HASIL PENELITIAN DAN PEMBAHASAN}

Data yang digunakan untuk analisis data pendahuluan dalam penelitian ini adalah nilai Semester Penilaian Akhir Ganjil yaitu kelas X Matematika dan Ilmu Pengetahuan Alam 1 dan X Matematika dan kelas X Ilmu Pengetahuan Alam 8 di salah satu SMA di Banyumas 2018/2019 Akademik Tahun. Hasil analisis ini dilakukan untuk mengetahui kemampuan awal kelas eksperimen dan kontrol untuk memiliki kondisi yang sama atau tidak. Uji normalitas, uji homogenitas dan dua kesamaan rata-rata dengan nilai Penilaian Akhir Semester.

Uji normalitas digunakan untuk menentukan apakah data awal normal atau tidak. Uji normalitas yang digunakan dalam penelitian ini adalah KolmogorovSmirnov dengan SPSS. Berdasarkan output SPSS dari uji normalitas kelas eksperimen diperoleh sig $=0,087>\alpha$ dan kelas kontrol diperoleh sig $=0,058>\alpha$. Berdasarkan kriteria ini, H0 diterima. Ini menunjukkan bahwa data Nilai Penilaian Semester Akhir dari kelas eksperimen dan kelas kontrol berasal dari populasi yang berdistribusi normal.

Uji homogenitas digunakan untuk mengetahui apakah kedua kelompok sampel memiliki varian yang sama atau tidak, jika mereka memiliki varian yang sama, mereka dikatakan homogen. Uji homogenitas yang digunakan dalam penelitian ini adalah Levene dengan SPSS. Berdasarkan output SPSS, sig=0,496> $\alpha$ diperoleh. Berdasarkan kriteria ini, H0 diterima. Ini menunjukkan bahwa kedua sampel memiliki varian yang sama (homogen).

Uji kesamaan rata-rata dilakukan untuk mengetahui apakah dua sampel yang dipilih memiliki kondisi kemampuan awal yang sama. Karena data awal 
normal dan homogen, tes yang digunakan adalah uji t. Dikatakan tidak ada perbedaan rata-rata jika 【-t) _ $(1-1 / 2 \alpha)<t_{\text {_count }}<\mathrm{t}_{-}(1-1 / 2 \alpha)$. Berdasarkan tes yang telah dilakukan diperoleh $\mathrm{t} \_$count $=0,1111$, $\mathrm{t} \_$table $=1,99$ dan $-\mathrm{t} \_$table $=$ -1,99. Berdasarkan kriteria pengujian, H0 diterima. Dapat disimpulkan bahwa Penilaian Semester Akhir rata-rata antara kelas eksperimen dan kelas kontrol adalah sama.

Implementasi pembelajaran di kelas eksperimen dan kelas kontrol dilakukan dalam 4 pertemuan. Tes Kemampuan Koneksi Matematika dilakukan di kelas eksperimen dengan 34 siswa dan kelas kontrol dengan 34 siswa. Tes dilakukan selama 80 menit dengan total 6 pertanyaan. Setelah tes hasil jawaban dianalisis berdasarkan uji proporsi, uji kesamaan dua rata-rata, dan uji kesamaan dua proporsi. Hasil uji hipotesis adalah sebagai berikut.

Tes Hipotesis 1 bertujuan untuk menguji jumlah siswa yang menyelesaikan secara individual (skor tes lebih dari Kriteria Kelengkapan Minimum) lebih dari 75\%. Tes kelengkapan klasik ini menggunakan tes proporsi satu pihak, yaitu hak. Hasil perhitungan diperoleh $Z$ _count $=1,386$ dan Z_table $=0,64$. Berdasarkan kriteria pengujian $Z_{-}$count $\geq Z$ _table maka $\mathrm{H} 0$ ditolak. Ini berarti bahwa kemampuan koneksi matematis siswa dalam materi perbandingan trigonometri pada segitiga siku-siku menggunakan pembelajaran PACE adalah lengkap secara klasik.

Uji Hipotesis 2 bertujuan untuk menganalisis apakah kemampuan koneksi matematika rata-rata siswa pada materi perbandingan trigonometri pada segitiga siku-siku menggunakan pembelajaran PACE lebih baik daripada kemampuan koneksi matematika siswa yang menggunakan Problem Based Learning. Uji hipotesis 2 menggunakan uji kemiripan rata-rata dua, yaitu uji-t. Hasil perhitungan diperoleh $t \_$count $=2.319$ dan $t$ ttable $=1.996$. Berdasarkan kriteria pengujian $t_{\text {hitung }}>t_{\text {tabel }}$ maka $H_{0}$ ditolak. Ini berarti bahwa kemampuan koneksi matematika rata-rata siswa dengan pembelajaran PACE lebih baik daripada kemampuan koneksi matematika rata-rata dengan Pembelajaran Berbasis Masalah. 
Tes Hipotesis 3 bertujuan untuk mengetahui apakah proporsi siswa yang tuntas di kelas menggunakan pembelajaran PACE lebih dari proporsi siswa yang tuntas di kelas yang menggunakan Pembelajaran Berbasis Masalah. Uji hipotesis 3 menggunakan uji kesamaan dua proporsi. Hasil perhitungan $Z_{\text {hitung }}=1,96$ dan $\mathrm{Z}_{\text {tabel }}=1,64$. Berdasarkan kriteria pengujian $\mathrm{Z}_{\text {hitung }} \geq \mathrm{Z}_{\text {tabel }}$ maka $\mathrm{H}_{0}$ ditolak. Ini berarti bahwa proporsi siswa yang telah menyelesaikan kelas menggunakan pembelajaran PACE lebih dari proporsi siswa yang telah menyelesaikan kelas menggunakan Pembelajaran Berbasis Masalah.

\section{SIMPULAN}

Berdasarkan hasil penelitian dan diskusi diperoleh kesimpulan sebagai berikut: Pembelajaran PACE efektif terhadap kemampuan koneksi matematika siswa kelas $\mathrm{X}$ yang ditandai oleh (i) hasil tes kemampuan koneksi matematika siswa dengan pembelajaran PACE yang mencapai ketuntasan klasikal; (ii) ratarata kemampuan koneksi matematika siswa dengan pembelajaran PACE lebih baik daripada rata-rata kemampuan koneksi matematika dengan Problem Based Learning (PBL), dan (iii) proporsi siswa yang menyelesaikan pembelajaran PACE lebih dari proporsi siswa yang memiliki dilengkapi dengan Pembelajaran Berbasis Masalah.

\section{DAFTAR PUSTAKA}

Creswell, J. W. (2015). Riset Pendidikan: Perencanaan, Pelaksanaan, dan Evaluasi Riset Kualitatif \& Kuantitatif ( $5^{\text {th }}$ ed.). Translated by Soetjipto, H. P. \& S. M. Soetjipto. 2015. Yogyakarta: Pustaka Pelajar.

Dewi, N. R. \& Masrukan. (2018). Kemampuan Koneksi Matematis Mahasiswa Calon Guru pada Brain Based Learning Berbantu Web. Jurnal Matematika Kreatif-Inovatif, 9(2): 204-214.

Dewi, N. R. \& Kusumah, Y.S. (2014). Developing Test of High Order Mathematical Thinking Ability In Integral Calculus Subject. International Journal of Education and Research, 2(12): 101-108.

Karnasih, I. \& Sinaga, M. (2014). Echancing Mathematical Problem Solving and Mathematical Connection Though the Use of Dynamic Software Autigraph in Cooperative Learning Think Pair Share. SAINSAB-The Journal of The Association For Science and Mathematics Education, 17: 51-71. 
Lee, C. (1998). An Assesment of the PACE Strategy for an Introductory Statistics Course, ICOTS, 5: 1245-1249.

OECD. (2016). PISA 2015 Results in Focus. New York: Columbia City.

Prasetyo, A., Dwidayati, N.K. \& Junaedi, I. (2017). Students's Mathematical Connection Ability and Disposition Reviewed by Keirsey Personality Type through Eliciting Activities Mathematics Learning Model. Unnes Journal of Mathematics Education, 6(2): 190-197.

NCTM. (2000). Principles and Standards for School Mathematics. Amerika: The National Council of Teachers of Mathematics, Inc.

Noto, M. S., Hartono, W. \& Sundawan, M. D. (2016). Analysis of Students Mathematical Representation and Connection on Analytical Geometry Subject. Infinity, 5(2): 99-108.

Saminanto, \& Kartono. (2015). Analysis of Mathematical Connection Ability in Linear Equation With One Variable Based on Connectivity Theory. International Journal of Education and Research, 3(4): 259-270.

Suryana. (2015). Analisis Implementasi Model PACE pada Mata Kuliah Statistika Matematika. Jurnal Kajian Pendidikan Matematika, 1(1): 91-105.

Padmavathy, R. D. \& Mareesh, K. (2013). Effectiveness of Problem based Learning In Mathematics. International Multidisciplinary e-Journal, 2(1): 45-51. 